\title{
Asian American History Forum: Introduction
}

\author{
MAE M. NGAI \\ The author is a member of the history department at Columbia University. \\ This introduction considers the ways that the following articles by Erika Lee, Dorothy \\ Fujita-Rony, Judy Tzu-Chun Wu, and Paul Spickard contribute to new directions in \\ the study of Asian American history and transnationalism.
}

During the last five to seven years there has been an enormous outpouring of scholarship in Asian American history that not only has transformed the field of Asian American studies but also has influenced history and American studies more broadly. Asian American historical scholarship has exemplified new heuristic frameworks and research methodologies and has produced new knowledge that has changed the way we think about Asian American and American history. ${ }^{1}$ Some of the most noteworthy advances have been in transnational and diasporic-migration studies, in the study of the nation and colonialism, and in intersectional analyses of race/ethnicity and gender/sexuality. The new scholarship

\footnotetext{
I thank the editors of the Pacific Historical Review for organizing this forum and the authors and discussants for their contributions.

1. Elsewhere I have hypothesized that these intellectual innovations may be explained in part by the unusual conditions of knowledge production that attended the doctoral education of the generation of Asian Americanists studying during the 1990s. Of the dissertations on Asian American history completed between 1990 and 2005, 86 percent were supervised by non-specialists and more than half were completed at universities in the northeastern and midwestern United States. Inspired by the founding generation of Asian American scholars, who legitimated the field within academia and built undergraduate Asian American studies programs, this next generation of Asian Americanists training in traditional history departments had to communicate and justify their ideas to advisers who had little or no background in the field. While non-specialists came to appreciate that Asian American history was not marginal but in fact posed important questions for U.S. and Asian history, graduate students also connected their work to broader historical themes and methods. Mae M. Ngai, "Asian American History-Reflections on the De-centering of the Field," Journal of American Ethnic History, 25 (Summer 2006), 97-108.
}

Pacific Historical Review, Vol. 76, No. 4, pages 533-535. ISSN 0030-8684 (C) 2007 by the Regents of the University of California. All rights reserved.

Please direct all requests for permission to photocopy or reproduce article content through the University of California Press's Rights and Permissions website, at http://www.uspressjournals .com/reprintinfo.asp DOI: phr.2007.76.4.533. 
has been both analytically innovative-broadening our range of vision of migration and settlement patterns; the circuitry of culture and politics; the reach of states' power and ambitions on the global stage; the myriad elements that constitute immigrant and national identities - and based on extensive empirical research, often conducted in more than one national archive and with sources in more than one language. It is the combination of conceptual sophistication and deep empirical grounding that accounts for the influence of this work. ${ }^{2}$

In this forum on new directions in Asian American history, one gets the sense of even broader analytical horizons coming into view. The essays presented here by Erika Lee, Dorothy Fujita-Rony, and Judy Tzu-Chun Wu describe, respectively, their current research projects (in each case, the author's second book); Paul Spickard's contribution discusses the past and future construction of "Asian American" as a political and research concept. Two Americanists with interests in transnational and Pacific-world history, Thomas Bender and David Igler, comment on the four essays to round out the forum.

2. Publications that exemplify these intellectual trends include: John Kuo Wei Tchen, New York before Chinatown: Orientalism and the Shaping of American Culture, 17761882 (Baltimore, 1999); Adam McKeown, Chinese Migrant Networks and Cultural Change: Peru, Chicago, Hawaii, 1900-1936 (Chicago, 1999); Madeline Y. Hsu, Dreaming of Gold, Dreaming of Home: Transnationalism and Migration between the United States and South China, 1882-1943 (Stanford, Calif., 2000); Yong Chen, Chinese San Francisco, 1850-1943: A Transpacific Community (Stanford, Calif., 2000); Nayan Shah, Contagious Divides: Epidemics and Race in San Francisco's Chinatown (Berkeley, 2001); Henry Yu, Thinking Orientals: Migration, Contact, and Exoticism in Modern America (New York, 2002); Catherine Ceniza Choy, Empire of Care: Nursing and Migration in Filipino American History (Durham, N.C., 2003); Erika Lee, At America's Gates: Chinese Immigration during the Exclusion Era, 1882-1943 (Chapel Hill, N.C., 2003); Dorothy B. Fujita-Rony, American Workers, Colonial Power: Philippine Seattle and the Transpacific West, 1919-1941 (Berkeley, 2003); Mary Ting Yi Lui, The Chinatown Trunk Mystery: Murder, Miscegenation, and Other Dangerous Encounters in Turn-of-the-Century New York City (Princeton, N.J., 2004); Augusto Espiritu, Five Faces of Exile: The Nation and Filipino American Intellectuals (Stanford, Calif., 2005); Eiichiro Azuma, Between Two Empires: Race, History, and Transnationalism in Japanese America (New York, 2005); Karen Leong, The China Mystique: Pearl S. Buck, Anna May Wong, Mayling Soong, and the Transformation of American Orientalism (Berkeley, 2005); Judy Tzu-Chun Wu, Doctor Mom Chung of the Fair-Haired Bastards: The Life of a Wartime Celebrity (Berkeley, 2005); Moon-Ho Jung, Coolies and Cane: Race, Labor, and Sugar in the Age of Emancipation (Baltimore, 2006); K. Scott Wong, Americans First: Chinese Americans and the Second World War (Cambridge, Mass., 2005); Linda España-Maram, Creating Masculinity in Los Angeles's Little Manila: Working-Class Filipinos and Popular Culture, 1920s-1950s (New York, 2006). 
Lee, Fujita-Rony, and Wu's projects are notable in that they each push on the concepts of "transnationalism" and "Asian American," although in quite different ways. Whereas in recent scholarship "transnational" has mostly involved tracking back-and-forth (or in-between) dynamics involving two nation-states and cultures, these essays propose frameworks that situate Asian American and U.S. history in regional, hemispheric, and global worlds. "Global history" might seem a vague, even impossible, concept, but here we see how the analytical leap might be accomplished: by directing our attention to certain structures (economic, legal, geopolitical) and specific themes and problems that work across (or constitute) those structures. Specifically, Lee examines the symbiotic development of anti-Asiatic discourses and legal regimes in the Americas and in the Pacific Rim in the early twentieth century. Fujita-Rony deploys the concept "land and water," reshaping the meaning of U.S. Western history and drawing attention to American colonial possessions in the Pacific and the role of Asian American "water workers" in the development of the West (seamen, fishermen, cannery workers). Wu considers the workings of "radical Orientalism" in Third World solidarity movements in the long decade of the 1960s.

Spickard reminds us of the historical and constructed nature of "Asian American" and urges us to think about new subjects such as biracial persons, transnational adoptees, and refugees. Lee, Fujita-Rony, and Wu's works index another development in Asian American studies, which broadens the frame beyond the single ethnic-group study. Lee shows how a racial discourse against all Asians grew throughout the Pacific world. Fujita-Rony's focus on water workers prompts a comparative study of different Asian ethnic groups in the region's economic development. Wu's subjects, activists of the 1960s, identified themselves as Asian Americans, whether they were of Chinese, Japanese, or other ancestry.

These projects by no means exhaust the range of work now being done in Asian American studies. They do offer a sample of the diverse ways in which scholars are pushing the boundaries of the field. 
This content downloaded from 128.59.222.12 on Wed, 24 Jun 2015 12:12:13 PM All use subject to JSTOR Terms and Conditions 